Annales Missiologici Posnanienses t. 25 (2020), s. 117-131

doi: $10.14746 / \mathrm{amp} .2020 .25 .8$

ORCID: 0000-0003-3513-0158

MARCIN WRZOS

Uniwersytet Stefana Kardynała Wyszyńskiego

Warszawa

\title{
Osoby o zadeklarowanym różnym stopniu religijności, a korzystanie $z$ internetowych mediów chrześcijańskich, w tym misyjnych, w Polsce. Badania pastoralno-prasoznawcze
}

Wśród użytkowników mediów internetowych są ludzie o rozmaitym stopniu religijności (deklarujący się jako wierzący i regularnie praktykujący, wierzący i okazjonalnie praktykujący oraz niewierzący). Osoby z tych trzech grup społecznych stały się przedmiotem badań w zakresie korzystania z nowych mediów komunikujących przez Internet. Nowe media, które na potrzeby badania definiujemy jako „techniki, technologie, a także instytucje służące do komunikacji, wykorzystujące metody cyfrowe do rejestracji, zapisywania, przechowywania danych, tworzenia i transmisji przekazów, charakteryzują się hipertekstową strukturą przekazu i odbioru, możliwością programowania (asynchronią nadawania i odbioru), interaktywnością, kumulatywnością, globalnym zasięgiem i jednocześnie indywidualizacją dostępu" (Chudziński 45). Teoretycy mediów dyskutują w kontekście ich definicji o tym, czy strony i portale internetowe należą do „nowych mediów”, czy tylko media społecznościowe. Wielu z nich (np. Lev Manovich) kwalifikuje wśród nowych mediów także strony i portale (Manovich 2003; Manovich 2006). Inni (np. Paul Levinson) proponują wyodrębnienie ich jako osobnej grupy mediów. Z czasem podejście Manovicha i Levinsona czy Magdaleny Szpunar, jak i innych medioznawców, uległo w Polsce dalszej ewolucji, w której efekcie rozróżnia się dzisiaj raczej komunikację za pomocą stron WWW, w tym portali i mediów społecznościowych, odchodząc od terminu „nowe media”. Stąd owo pojęcie nie jest już ostrym i transparentnym pojęciem (Szpunar 2008, 32; Szpunar 2010; Szpunar 2017, 3-134; Krzysztofek; Nieć; Konik; Goban-Klas; Hofman 308-317). Analizując prowadzone badania i uwzględniając spory dotyczące definicji wydaje 
się, że najwłaściwsze jest używanie sformułowań: „komunikacja za pomocą stron WWW oraz mediów społecznościowych”, „komunikacja za pomocą Internetu”, „media komunikujące za pomocą Internetu” lub „media internetowe” i pokrewnych.

Celem studium będzie określenie na reprezentatywnej grupie respondentów zamiaru samego korzystania z internetowych mediów chrześcijańskich, w tym misyjnych (wydaje się, że te ostatnie budzą szczególne zainteresowanie także osób niewierzących), treści i form przekazu dla nich najbardziej interesujących w trzech grupach badawczych. Będą to pierwsze tego rodzaju badania w Polsce, zrealizowane na taką skalę.

Wyodrębniono grupy: wierzących i regularnie praktykujących, wierzących i okazjonalnie praktykujących oraz niewierzących. Grupę badawczą będzie stanowić próba ogólnopolska, reprezentatywna według kwot zróżnicowanych na wiek, wykształcenie, region i wielkość miejscowości, a także religijność (osoby wierzące $\mathrm{w}$ podziale na regularnie oraz okazjonalnie praktykujących, $\mathrm{z}$ udziałem niewierzących i niezdecydowanych na poziomie udziału w populacji, a więc 10\%). Socjologiczne kwoty brzegowe będą proporcjonalne do rozkładów cech w populacji (dane Głównego Urzędu Statystycznego - zmienne społeczno-demograficzne i Instytutu Statystyki Kościoła Katolickiego - religijność Polaków), a wielkość próby wynosi $\mathrm{N}=1000$. Na potrzeby analizy zostały sformułowane następujące hipotezy i tezy badawcze, które potem, w toku badań, będziemy starali się zweryfikować (hipotezy) lub potwierdzić (tezy).

- Teza 1. W zależności od zadeklarowanego stopnia religijności zmienia się stopień znajomości i korzystania z internetowych mediów dotyczących wiary, religii i Kościoła, w tym misyjnych

- Hipoteza 1. Internetowe media chrześcijańskie docierają z przekazem do osób niewierzących

- Hipoteza 2. Internetowe media misyjne w większym stopniu budzą zainteresowanie osób niewierzących niż chrześcijańskie, internetowe media ogólnotematyczne

- Hipoteza 3. Internetowe media chrześcijańskie, w tym chrześcijańskie, podlegają procesowi atomizacji i zbytniej partykularyzacji.

Teologia środków społecznego przekazu bazuje na kilku metodach badawczych. Na potrzeby studium skorzystamy z dwuetapowej metodologii badań (Adamski i Łecicki; Mazzei). Pierwszym jej elementem jest poszukiwanie i opracowanie źródeł badawczych, a drugim interpretacja ich wyników w świetle Objawienia obecnego w Piśmie Świętym, poświadczonego przez Tradycję i Urząd Nauczycielski Kościoła, oraz wyprowadzenie wniosków 
i postulatów pastoralnych. Pierwszy etap niniejszych badań będzie poszerzony o metody badawcze znane z medioznawstwa i nauk społecznych (badania sondażowe ilościowe i jakościowe, analiza treści). Na badania sondażowe złożą się standaryzowane wywiady kwestionariuszowe CAWI (Computer-Assisted Web Interview - wspomagany komputerowo wywiad). To technika zbierania informacji w ilościowych i jakościowych badaniach rynku i opinii publicznej, w której respondent jest proszony o wypełnienie ankiety w formie elektronicznej, realizowanej na panelu badawczym. Drugim elementem badań sondażowych będą VIDI (Virtual Individual In-Depth Interviews), indywidualne wywiady pogłębione. Badania będą urzeczywistniane, zgodnie z pytaniami badawczymi, przez IQS Sp. z o.o., certyfikowaną firmę badawczą.

Niniejsze lapidarne studium podzielmy na następujące etapy badawcze:

1. Zainteresowanie treściami związanymi $\mathrm{z}$ wiarą/religią, Kościołem i misjami

2. Osoby wierzące i regularnie praktykujące a korzystanie z internetowych mediów chrześcijańskich, w tym misyjnych

3. Osoby wierzące i okazjonalnie praktykujące a korzystanie z internetowych mediów chrześcijańskich, w tym misyjnych

4. Osoby niewierzące a korzystanie z internetowych mediów chrześcijańskich, w tym misyjnych

5. Wnioski i postulaty pastoralne.

\section{Zainteresowanie treściami związanymi z wiarą/religią, Kościołem i misjami}

Media komunikujące za pomocą technologii internetowych to jedno $\mathrm{z}$ istotnych narzędzi przyczyniających się do ewangelizacyjnego oddziaływania. Taki stan stwarza konieczność sprawdzenia, jak duże zainteresowanie społeczne budzą wszystkie te media, które związane są zarówno z wiarą, jak i z religijnością, ale także z misjami, i które wydają się budzić zainteresowanie wśród osób deklarujących się jako niewierzące. Na pierwszym etapie badań zbadamy zainteresowanie mediami chrześcijańskimi, komunikującymi przez Internet.

Przeprowadzone badania wskazują, że 64\% respondentów $(\mathrm{N}=1000)$ interesuje się treściami opublikowanymi w nowych mediach powiązanych z (nie tylko chrześcijańską) wiarą i religijnością. 13\% z nich stwierdziło, że z całą pewnością zamierza nadal odwiedzać witryny dostarczające takie wiadomości, 20\% uważa, że jest to bardzo prawdopodobne, 31\% - niewykluczone. Mniejszość respondentów - 36\% - nie jest zainteresowana rzeczonymi tre- 


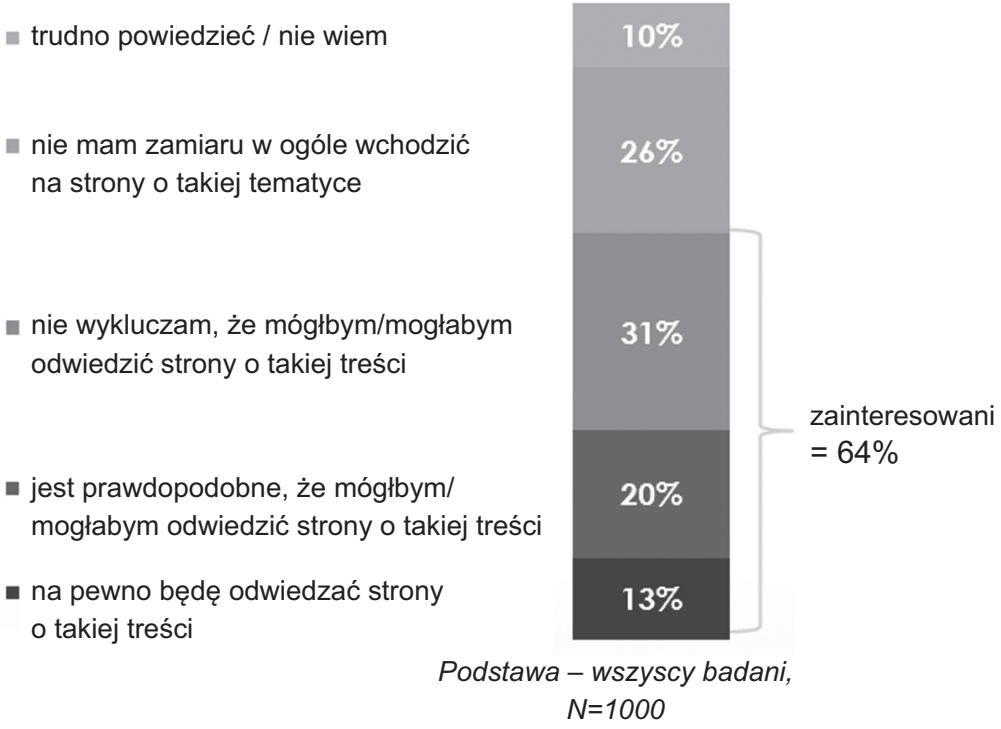

Wykres 1. Zainteresowanie mediami internetowymi, związanymi z wiarą/religią

ściami w nowych mediach, a 26\% badanych całkowicie wyklucza przeglądanie podobnych stron.

Szczegółowej analizie poddamy teraz osoby wykluczające korzystanie $\mathrm{z}$ nowych mediów związanych $\mathrm{z}$ wiarą i religią $(\mathrm{N}=261)$. Wśród nich jest odpowiednio $51 \%$ kobiet i $49 \%$ mężczyzn. Należą oni do następujących grup wiekowych: 18-24 lat - 7\%, 25-34 lat-14\%, 35-44 lat-19\%, 45-54 lat-14\% i $55+-45 \%$. Wykształcenie tych respondentów prezentuje się następująco: niepełne podstawowe $-0 \%$, podstawowe $-5 \%$, gimnazjalne $-2 \%$, zasadnicze zawodowe $-25 \%$, niepełne średnie (bez matury) - 7\%, średnie zawodowe $11 \%$, średnie ogólne $-8 \%$, policealne $-9 \%$, niepełne wyższe $-2 \%$, wyższe licencjackie lub inżynierskie - 5\%, wyższe magisterskie - $22 \%$, a stopień doktora otrzymało (lub ukończyło studia podyplomowe) - 3\%. Mieszkają one: samotnie $-14 \%$, z drugą osobą - $38 \%$, z dwiema osobami $-24 \%$, z trzema osobami $-14 \%$, z czterema osobami $-7 \%$, z pięcioma osobami $2 \%$ oraz z sześcioma i więcej - 1\% w jednym ognisku domowym. Najczęściej mieszkają na wsi $-33 \%$, w miasteczkach do 20 tys. mieszkańców - 10\%, w miastach od 20-49 tys. mieszkańców - 14\%, w miastach powyżej 500 tys. mieszkańców 17\%, w miastach od 100-199 tys. - 9\%, w miejscowościach od 200-500 tys. 9\%, a w miastach od 50-99 tys. - 8\%. Spośród tych osób $48 \%$ na co dzień podejmuje stałą pracę, $31 \%$ jest emerytem lub rencistą, $6 \%$ zajmuje się domem, $11 \%$ pracuje okazjonalnie, $5 \%$ jest w innej sytuacji zawodowej, $1 \%$ przebywa na urlopie wychowawczym bądź macierzyńskim, 3\% jest bezrobotne, 
$3 \%$ studiuje, a 4\% uczy się w szkole średniej lub policealnej, natomiast $24 \%$ wychowuje dziecko lub dzieci do 18 roku życia. Jeśli chodzi o religię 70\% z nich deklarowało się jako chrześcijanie, $0 \%$ jako żydzi, $0 \%$ jako muzułmanie, $0 \%$ jako buddyści, $1 \%$ jako osoby innego wyznania, $26 \%$ jako ateiści lub agnostycy, a 3\% osób biorących udział w badaniu odmówiło odpowiedzi na pytania. Wśród chrześcijan najwięcej jest katolików - 98\%, następnie prawosławnych $-1 \%$, świadków Jehowy po $1 \%$, zielonoświątkowców i protestantów po $0 \%$. Osoby z tej grupy respondentów w $2 \%$ uczestniczą tygodniowo parokrotnie w praktykach religijnych, w 13\% raz w tygodniu, w 7\% raz lub dwa razy w miesiącu, w 36\% raz lub kilka razy w roku, a w 43\% nie uczestniczą w praktykach religijnych.

W przeprowadzonym badaniu uwidacznia się niedoreprezentowane osób będących zdeklarowanymi wierzącymi $\mathrm{w}$ odniesieniu do ich zainteresowania mediami internetowymi, związanymi z wiarą i religią. Prawdopodobnie jest to rezultat ich słabych umiejętności w posługiwaniu się Internetem (czynnikiem jawi się wiek), niedostosowania do ich potrzeb treści publikowanych w chrześcijańskich mediach internetowych, braku potrzeby posiadania informacji oraz formacji chrześcijańskiej. Biorąc pod uwagę płeć, rzeczonymi mediami bardziej zainteresowane są kobiety. Zainteresowanie internetowymi mediami chrześcijańskimi rośnie proporcjonalnie z wiekiem, co oznacza, że chętniej odwiedzane są przez osoby starsze (nadreprezentacja) niż przez młodszych użytkowników, choć młodsi stanowią większy odsetek surfujących po Internecie. Tendencja wzrostowa jest odwrotnie proporcjonalna do wykształcenia, a analizowane media częściej przeglądane są przez osoby żyjące w złożonym z wielu osób ognisku domowym. Najmniejsze zainteresowanie rzeczonymi mediami wyrażają osoby pochodzące z centralnej i północno-zachodniej Polski, największe zaś ze Śląska i województw południowo-wschodnich. Respondenci pochodzący z większych miast wykazują znacznie mniejszą chęć zaznajamiania się z nowymi mediami odnoszącymi się do wiary i religii. Odwrotna tendencja występuje u mieszkańców ośrodków miejskich do 100 tys. Jak pokazują badania, na zainteresowanie opisywanymi mediami nie ma wpływu zawód ani wysokość dochodów. Godna podkreślenia jest jednak intrygująca zależność występująca u rodzin z dziećmi do 18 roku życia, w których zainteresowanie nowymi mediami chrześcijańskimi wśród respondentów jest znacznie większe.

Na pytanie bardziej szczegółowe, dotyczące zainteresowania mediami internetowymi, związanymi z Kościołem i misjami (zawężenie pytania w stosunku do badania zainteresowania wiarą i religijnością), 56\% respondentów odpowiedziało, że są nimi zainteresowani, $20 \%$ z nich deklaruje, że na pewno będzie wchodziło na strony o takiej treści, a 16\%, że wprawdzie interesują ich misje, ale nie Eklezja, a 20\%, że internetowe media związane z Kościołem tak, ale nie z misjami. Negatywnie na to pytanie odpowiedziało $44 \%$ respon- 
n trudno powiedzieć / nie wiem

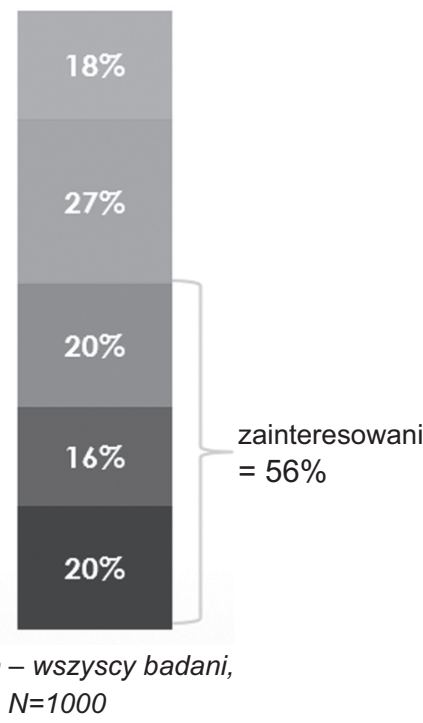

Wykres 2. Zainteresowanie nowymi mediami związanymi z Kościołem i misjami

dentów. Wśród nich 27\% wykluczyło taką możliwość, a 18\% trudno było odpowiedzieć na to pytanie lub nie chcieli udzielić odpowiedzi. Zastanawiający jest tak wysoki odsetek osób negatywnie nastawionych do korzystania z eklezjalnych i misyjnych nowych mediów.

Ze szczegółowych analiz osób, które na pewno nie będą korzystać z internetowych mediów dotyczących kwestii związanych z Kościołem i misjami wynika, że wśród nich $(\mathrm{N}=266)$ jest odpowiednio po 50\% kobiet i mężczyzn. Należą oni do następujących grup wiekowych: 18-24 lat - 8\%, 25-34 lat $13 \%, 35-44$ lat $-20 \%, 45-54$ lat $-13 \%$ i $55+-45 \%$. Wykształcenie tych respondentów jest następujące: niepełne podstawowe $-0 \%$, podstawowe $-6 \%$, gimnazjalne $-3 \%$, zasadnicze zawodowe $-25 \%$, niepełne średnie (bez matury) $-8 \%$, średnie zawodowe $-10 \%$, średnie ogólne $-8 \%$, policealne $-9 \%$, niepełne wyższe - 3\%, wyższe licencjackie lub inżynierskie - $6 \%$, wyższe magisterskie - $19 \%$ i ze stopniem doktora lub ze studiami podyplomowymi $-3 \%$. Mieszkają oni samotnie $-13 \%$, z drugą osobą - 39\%, z dwiema osobami $-24 \%$, z trzema osobami - $13 \%$, z czterema osobami $-7 \%$, z pięcioma osobami $2 \%$ i z sześcioma oraz większą ilością osób - $1 \% \mathrm{w}$ jednym ognisku domowym. Najczęściej mieszkają na wsi - 36\%, w miasteczkach do 20 tys. mieszkańców - 9\%, w miastach od 20-49 tys. mieszkańców - 15\%, w miastach powyżej 500 tys. mieszkańców - 15\%, w miastach od 100-199 tys. 8\%, w miejscowościach od 200-500 tys. - 9\%, a w miastach od 50-99 tys. - 8\%. Spośród tych osób $48 \%$ na co dzień podejmuje stałą pracę, 32\% jest 
emerytem lub rencistą, 5\% zajmuje się domem, 11\% pracuje okazjonalnie, 5\% jest w innej sytuacji zawodowej, $2 \%$ przebywa na urlopie wychowawczym lub macierzyńskim, 3\% jest bezrobotne, 3\% studiuje, a 5\% uczy się w szkole średniej lub policealnej, natomiast $25 \%$ wychowuje dziecko lub dzieci do 18 roku życia. Jeśli chodzi o religię, to $70 \% \mathrm{z}$ nich deklarowało się jako chrześcijanie, $0 \%$ jako żydzi, $0 \%$ jako muzułmanie, $0 \%$ jako buddyści, $2 \%$ jako osoby innego wyznania, w $24 \%$ jako ateiści lub agnostycy, a 3\% osób biorących udział w badaniu odmówiło odpowiedzi na te pytania. Wśród chrześcijan najwięcej jest katolików - 98\%, następnie prawosławnych - 2\%, świadków Jehowy 1\%, zielonoświątkowców i protestantów po $0 \%$. Osoby z tej grupy respondentów w $2 \%$ uczestniczą parokrotnie w tygodniu w praktykach religijnych, w $16 \%$ raz $\mathrm{w}$ tygodniu, w $6 \%$ raz lub dwa razy w miesiącu, w 35\% raz lub kilka razy w roku, a w $41 \%$ wcale nie uczestniczą w praktykach religijnych.

Poprzez badania wyraźnie uwidoczniony jest niższy od poziomu zainteresowania wiarą i religią poziom zainteresowania misjami (w zależności od porównywalnego wektora badań jest to pomiędzy 3 a 9\%). Podobnie jak i w poprzednim etapie, internetowymi mediami chrześcijańskimi bardziej zainteresowane są kobiety niż mężczyźni, a samo zainteresowanie wzrasta wraz $\mathrm{z}$ wiekiem (nadreprezentacja). Chęć do zapoznawania się z treściami w analizowanych mediach rośnie odwrotnie proporcjonalnie do wykształcenia, szczególnie w większych ogniskach domowych. Najmniej zainteresowani są nimi respondenci pochodzący z centralnych i północno-zachodnich województw, najbardziej osoby pochodzące ze Śląska i południowo-wschodniej Polski. Badani pochodzący z miast liczących do 100 tys. mieszkańców wyrażają największe zainteresowanie mediami internetowymi dotyczącymi Kościoła i misji, w większych miastach jest ono dużo mniejsze, a w ośrodkach powyżej 500 tys. - bardzo małe. Badania nie wykazały, że na zainteresowanie analizowanymi mediami wywiera wpływ wykonywany zawód czy wysokość dochodów - jest ono równomiernie rozłożone zarówno po stronie respondentów zainteresowanych, jak i po stronie respondentów niezainteresowanych tymi mediami. Intrygująca jest jednak zależność, że w rodzinach z dziećmi do 18 roku życia zainteresowanie tymi mediami jest wśród respondentów znacznie wyższe.

\section{Osoby wierzące i regularnie praktykujące a korzystanie z internetowych mediów chrześcijańskich, w tym misyjnych}

Wśród osób wierzących i regularnie praktykujących $8 \%$ respondentów nie ma zamiaru korzystać z mediów komunikujących za pomocą Internetu, związanych z wiarą i religijnością, 32\% respondentów nie wyklucza odwiedzin tych stron, 29\% uważa za prawdopodobne korzystanie z nich, 21\% deklaruje, że na 
pewno będzie z nich korzystać, a 9\% nie wie, czy będzie. Na pytanie związane $\mathrm{z}$ korzystaniem $\mathrm{z}$ internetowych mediów dotyczących kwestii związanych z Kościołem i misjami 10\% respondentów odpowiedziało, że nie ma zamiaru korzystać z nowych mediów związanych z Kościołem i misjami, 23\% respondentów nie wykluczyło odwiedzenia stron związanych z Kościołem, ale nie z misjami, $17 \%$ respondentów nie wykluczyło odwiedzenia stron związanych z misjami, ale nie z Kościołem, 34\% zadeklarowało, że na pewno będzie korzystać z tych stron, a 16\% nie wiedziało, czy będzie. Na pytanie „czy zna Pan/Pani jakiekolwiek media społecznościowe (Facebook, Instagram lub inne), poświęcone kwestiom misyjnym?", wśród osób deklarujących się jako wierzące i regularnie praktykujące $37 \%$ respondentów zadeklarowało, że zna, a $63 \%$, że nie. Wśród tych osób 53\% respondentów zadeklarowało, że zna strony i portale dotyczące misji i potrafił je wymienić, a 47\%, że nie. Na stronach i portalach misyjnych, spośród osób wierzących i praktykujących (potencjalny wybór do trzech możliwości) $51 \%$ respondentów poszukiwało tematyki misyjnej, 46\% tematyki związanej z kwestiami wiary, 30\% tematyki związanej z chrześcijanami prześladowanymi, 22\% tematyki związanej z dialogiem kultury, ekumenicznym i religii, 22\% tematyki związanej z sytuacją społeczną i polityczną w krajach tzw. Trzeciego Świata, 17\% z podróżami, 14\% z podmiotem prowadzącym dane medium, 5\% respondentów nie wiedziało, a 2\% szukało innych treści. Osoby wierzące i regularnie praktykujące wskazywały następujące atrakcyjne dla nich formy przekazu treści misyjnych w nowych mediach (potencjalny wybór do pięciu możliwości): 56\% historie z życia misjonarza, $50 \%$ fotoreportaże, $49 \%$ filmy, $46 \%$ galerie zdjęć, 44\% wywiady, $42 \%$ świadectwa, 33\% artykuły misyjne, 26\% felietony, $23 \%$ transmisje live, $22 \%$ newsy, $20 \%$ raporty, $17 \%$ rysunki/grafiki i $4 \%$ żadne z powyższych.

\section{Osoby okazjonalnie praktykujące a korzystanie $\mathrm{z}$ internetowych mediów chrześcijańskich, w tym misyjnych}

Wśród osób okazjonalnie praktykujących 33\% respondentów nie ma zamiaru korzystać z internetowych mediów związanych $\mathrm{z}$ wiarą i religijnością, $33 \%$ respondentów nie wyklucza odwiedzin tych stron, $15 \%$ uważa za prawdopodobne korzystanie z nich, $6 \%$ deklaruje, że na pewno będzie korzystać $\mathrm{z}$ tych stron, a $12 \%$ nie wie, czy będzie. Na pytanie związane z korzystaniem z internetowych mediów dotyczących kwestii związanych z Kościołem i misjami 33\% respondentów odpowiada, że nie zamierza korzystać z nowych mediów związanych z Kościołem i misjami, 19\% respondentów nie wyklucza odwiedzenia stron związanych z Kościołem, ale nie z misjami, 16\% respondentów nie wyklucza odwiedzenia stron związanych z misjami, ale nie z Ko- 
ściołem, 10\% deklaruje, że na pewno będzie korzystać z tych stron, a 22\% nie wie, czy będzie. Na pytanie „,czy zna Pan/Pani jakiekolwiek media społecznościowe (Facebook, Instagram lub inne) poświęcone kwestiom misyjnym?", wśród osób deklarujących się jako wierzące i regularnie praktykujące $37 \%$ respondentów zadeklarowało, że zna, a 63\%, że nie. Wśród tych osób $34 \%$ respondentów zadeklarowało, że zna strony i portale dotyczące misji i potrafiło je wymienić, a $66 \%$, że nie. Na stronach i portalach misyjnych, spośród osób wierzących i okazjonalnie praktykujących (potencjalny wybór do trzech możliwości) 35\% respondentów poszukiwało tematyki misyjnej, 31\% tematyki związanej z kwestiami wiary, 15\% tematyki związanej z chrześcijanami prześladowanymi, $16 \%$ tematyki związanej z dialogiem kultury, ekumenicznym i religii, 24\% tematyki związanej z sytuacją społeczną i polityczną w krajach tzw. Trzeciego Świata, $26 \%$ z podróżami, $12 \%$ z podmiotem prowadzącym dane medium, $10 \%$ respondentów nie wiedziało, czego poszukuje, a $2 \%$ szukało innych treści. Osoby wierzące i okazjonalnie praktykujące wskazywały następujące, atrakcyjne dla nich formy przekazu treści misyjnych w nowych mediach (potencjalny wybór do pięciu możliwości): $56 \%$ galerie zdjęć, 52\% historie z życia misjonarza, 51\% fotoreportaże, 47\% filmy, 39\% wywiady, $33 \%$ artykuły misyjne, 26\% felietony, 25\% transmisje live, $23 \%$ newsy, 23\% raporty, 23\% świadectwa, 14\% rysunki/grafiki, a 4\% żadne z powyższych.

\section{Osoby niewierzące a korzystanie $\mathrm{z}$ internetowych mediów chrześcijańskich, w tym misyjnych}

Wśród osób niewierzących $76 \%$ respondentów nie ma zamiaru korzystać $\mathrm{z}$ mediów internetowych, związanych $\mathrm{z}$ wiarą i religijnością, $12 \%$ respondentów nie wyklucza odwiedzenia tych stron, $6 \%$ uważa za prawdopodobne korzystanie z nich, $2 \%$ deklaruje, że na pewno będzie korzystać z takich witryn, a $4 \%$ nie wie, czy będzie. Na pytanie związane z korzystaniem z internetowych mediów dotyczących kwestii związanych z Kościołem i misjami 73\% respondentów odpowiedziało, że nie zamierza korzystać z nowych mediów związanych z Kościołem i misjami, 7\% respondentów nie wyklucza odwiedzenia stron związanych z Kościołem, ale nie z misjami, 13\% respondentów nie wyklucza odwiedzenia stron związanych z misjami, ale nie z Kościołem, $1 \%$ deklaruje, że na pewno będzie korzystać z tych stron, a $6 \%$ nie wie, czy będzie. Na pytanie: „Czy zna Pan/Pani jakiekolwiek media społecznościowe (Facebook, Instagram lub inne), poświęcone kwestiom misyjnym”, wśród osób deklarujących się jako niewierzące $0 \%$ respondentów zadeklarowało, że zna, a 100\%, że nie. Wśród tych osób $11 \%$ respondentów zadeklarowało, że 
zna strony i portale dotyczące misji i potrafiło je wymienić, a $89 \%$, że nie. $\mathrm{Na}$ stronach i portalach misyjnych, spośród osób niewierzących (potencjalny wybór do trzech możliwości) 31\% respondentów poszukiwało tematyki misyjnej, $7 \%$ tematyki związanej z kwestiami wiary, 6\% tematyki związanej z chrześcijanami prześladowanymi, 29\% tematyki związanej z dialogiem kultury, ekumenicznym i religii, 36\% tematyki związanej z sytuacją społeczną i polityczną w krajach tzw. Trzeciego Świata, $25 \%$ z podróżami, $0 \%$ z podmiotem prowadzącym dane medium, $0 \%$ respondentów nie wiedziało, a $13 \%$ innych treści. Osoby niewierzące wskazywały następujące, atrakcyjne dla nich formy przekazu treści misyjnych w nowych mediach (potencjalny wybór do pięciu możliwości): 45\% historie z życia misjonarza, 35\% filmy, 35\% wywiady, 23\% artykuły misyjne, 23\% świadectwa, 13\% galerie zdjęć, 11\% fotoreportaże, $11 \%$ felietony, $11 \%$ transmisje live, $0 \%$ newsy, $0 \%$ raporty, $0 \%$ rysunki/grafiki i $21 \%$ żadne z powyższych.

\section{Wnioski i postulaty pastoralne}

Wobec nowych wyzwań technologicznych Kościół nie pozostaje obojętny. Dostrzega w najnowszych technologiach potencjał i szansę dla ewangelizacji, która w myśl słów Jezusa Chrystusa: „Idźcie więc i nauczajcie wszystkie narody" (Mt 28,19) pragnie urzeczywistniać to wezwanie w każdej czasoprzestrzeni z wykorzystaniem rozmaitych środków przekazu. Tę intuicję pastoralną rozwinął Sobór Watykański II (Sobór Watykański II 2005a; Sobór Watykański II 2005b) wraz z późniejszym nauczaniem Kościoła, chociażby Adhortacją apostolską Christifideles laici (Jan Paweł II 1988) czy z orędziami na Światowy Dzień Środków Społecznego Przekazu. Kwestię obecności Kościoła w środkach społecznego przekazu komunikujących przez Internet omawiali polscy badacze (Kloch 2011; Hajduk; Domaszk 81-94; Wielebski, 52-59; Przybyłowski 13-20; Łęcicki 117-172; Nogowski; Umiński; Śniadach; Wajs, Kuciński). Teologowie zajmujący się środkami społecznego przekazu zauważają, że o ile do niedawna „Kościół prowadził misje i przenosił ziarno Ewangelii z kontynentu na kontynent, o tyle na przełomie XX i XXI w. po narodzeniu Chrystusa wkroczył na zupełnie "nową ziemię" (Kloch 2013, 21). Pozytywy jak i negatywy związane z mediami komunikującymi przez Internet, także jako narzędziami działalności ewangelizacyjnej, wskazywali trzej ostatni papieże, zwłaszcza w orędziach na Światowy Dzień Środków Społecznego Przekazu. Pierwszym z papieży, który dostrzegł szczególną rolę Internetu, był Jan Paweł II. W orędziu na Światowy Dzień Środków Społecznego Przekazu pisał o „erze komputerów” i wykorzystywaniu „skomputeryzowanych systemów uczestnictwa” (Jan Paweł II 1990), czyli Internetu, do reali- 
zacji misji Kościoła. Było to w roku 1990, jeszcze przed powstaniem pierwszej strony internetowej w języku polskim. Kolejni dwaj papieże, w zasadzie corocznie, swoją uwagę koncentrowali wokół tzw. nowych mediów. Papież Benedykt XVI nazywa Internet „cyfrowym kontynentem, który powinien być ewangelizowany, ale też ewangelizuje" (Benedykt XVI), nawiązując do pierwszych wypraw ewangelizacyjnych nowożytnego świata, a papież Franciszek ukazuje media internetowe jako praktyczne narzędzia, które powinny pozwolić na przejście od wspólnoty wirtualnej do realnej w Kościele, a także przestrzega przed zjawiskiem, jakimi są face news, jak i przed deepfake (Franciszek 2019; Franciszek 2020). Wszyscy trzej ostatni biskupi Rzymu postulują, by wykorzystywać internetowe środki społecznego przekazu w dziele ewangelizacji. Ta obecność powinna być możliwie profesjonalna, a obecność Kościoła i duchowieństwa przemyślana i zaprogramowana. Głoszenie Dobrej Nowiny ma odbywać się bezpośrednio, przez treści chrześcijańskie (katechezę, informacje o Kościele, świadectwa, rozważania biblijne, modlitwę, transmisję sakramentów itd.), a także i pośrednio przez prawdziwe i rzetelne informacje nieskupiające się na sensacji, ale na dobru odbiorcy. Biskupi Rzymu zauważają, że wiara, wspólnota wirtualna potencjalnie doprowadzą ludzi do spotkania na łamaniu chleba $\mathrm{w}$ realnym Kościele. Cyberświat nie zastąpi realnego świata i intymnej relacji z Bogiem. Dostrzegają także możliwość prowadzenia, dzięki środkom społecznego przekazu, dialogu kultury, religii, grup społecznych, a w nich możliwość tworzenia nowych więzów, które będą otwarte na niesienie pomocy.

Wyniki badań prowadzą do następujących wniosków i postulatów pastoralnych:

- konieczna jest profesjonalizacja obecności w mediach internetowych, dotycząca zarówno treści, jak i formy. Postuluje się, by zajmowały się nimi, na szczeblu instytucji ogólnopolskich, osoby przygotowane pod względem teologicznym (misjologicznym), dziennikarskim i informatycznym. Słaba jakość merytoryczna i techniczna nie gwarantuje korzystania z tych środków społecznego przekazu

- należy budować pozytywny wizerunek Kościoła. Wiadomości chrześcijańskie, w tym misyjne, a szczególnie te związane z szeroko pojętą działalnością na rzecz promocji człowieka, powinny być wykorzystywane w eklezjalnym przekazie medialnym jako kreujące pozytywny wizerunek Kościoła i konieczne jest ukazanie jego powszechności, co nie zawsze ma miejsce. Media misyjne mają szansę być driverem (tematyka budząca zainteresowanie, przyciągająca) prowadzącym do korzystania z pozostałych mediów chrześcijańskich oraz do przyjęcia orędzia o zbawieniu w Jezusie Chrystusie przez osoby sporadycznie praktykujące lub obojętne religijnie 
- przejście od e-spotkania do realnego uczestnictwa w życiu Kościoła. Osoby prowadzące media misyjne, komunikujące przez Internet, jak i ogólnochrześcijańskie (duchowni i świeccy) powinny mieć na uwadze to, że $e$-spotkanie ma doprowadzić do realnego spotkania z Bogiem w Kościele

- należy stworzyć płaszczyznę współpracy i strategii ewangelizacyjno-medialnej. Istnieje konieczność współpracy (formacyjnej, szkoleniowej, informacyjnej) TOP10 internetowych mediów chrześcijańskich i TOP5 internetowych mediów misyjnych w Polsce, aby realizować wspólne elementy opracowanej strategii ewangelizacyjno-medialnej, w tym wykorzystania frontmanów i influencerów, czy prowadzenia chrześcijańskich kampanii społecznych ogólnokrajowych. Warto wykorzystać działające struktury Biura Prasowego Episkopatu Polski i Krajowej Rady Misyjnej

- zauważalna jest atomizacja mediów chrześcijańskich i misyjnych, brak spójnego przekazu, który często wyklucza się. Nieukazywanie Kościoła jako wspólnoty ponadnarodowej nie sprzyja przekazywaniu nauczania o jego powszechności

- wykorzystanie driverów i form atrakcyjnych dla odbiorców. Zastosowanie przeprowadzonych badań sprzyja dotarciu do szerszego grona odbiorców z Dobrą Nowiną dzięki zastosowaniu form dziennikarskich, tematów interesujących odbiorców z grupy osób niewierzących lub okazjonalnie praktykujących

- wypracowanie strategii ewangelizacyjno-medialnych komunikujących za pomocą Internetu mediów misyjnych. Zazwyczaj, żeby intuicyjne i labilne (falowe, niestałe) prowadzenie internetowych mediów przynosiło planowane efekty, powinno bazować na jasnej strategii działań, m.in. poprzez dopasowanie treści do rodzaju medium i jego grupy docelowej.

Bazując na toku przeprowadzonych analiz, możemy następująco potwierdzić lub zweryfikować postawione tezy i hipotezy badawcze:

- Teza 1: „W zależności od zadeklarowanego stopnia religijności zmienia się stopień znajomości i korzystania z internetowych mediów dotyczących wiary, religii i Kościoła, w tym misyjnych" została potwierdzona

- Hipoteza 1: „Internetowe media chrześcijańskie docierają z przekazem do osób niewierzących" została zweryfikowana negatywnie

- Hipoteza 2: „Internetowe media misyjne w większym stopniu budzą zainteresowanie osób niewierzących niż chrześcijańskie, internetowe media ogólnotematyczne" została zweryfikowana pozytywnie

- Hipoteza 3: „Internetowe media chrześcijańskie, w tym chrześcijańskie, podlegają procesowi atomizacji i zbytniej partykularyzacji” została zweryfikowana pozytywnie. 


\section{PEOPLE WITH VARIOUS DEGREES OF RELIGIOSITY DECLARED, AND USE OF ONLINE PEOPLE WITH VARIOUS DEGREES OF DECLARED RELIGIOSITY, AND THE USE OF ONLINE CHRISTIAN MEDIA, INCLUDING MISSIONARY MEDIA, IN POLAND. A PASTORAL AND PRESS RESEARCH}

\section{Summary}

Media communicating via the Internet have become tools of evangelizing influence since the early 1990s. They became the subject of research for the author, in terms of how well they are known to the Internet users depending on the degree of religiosity they declared (believers and regular users, believers and occasional practitioners, non-believers), which allowed to formulate pastoral postulates and conclusions. The survey included persons from a representative, nationwide sample $(\mathrm{N}=1000)$ who completed standardized CAWI (Computer-Assisted Web Interview) questionnaire interviews and VIDI (Virtual Individual In-Depth Interviews - individual indepth interviews). This is the first such extensive research on Poland. According to the research, the knowledge and use of Christian media that communicate through the Internet, including the missionary ones, changes depending on the respondents' declared degree of religiosity.

Keywords: new media; Internet; missions; degree of religiosity; use

Słowa kluczowe: nowe media; Internet; misje; stopień religijności; korzystanie

\section{BIBLIOGRAFIA}

Adamski Andrzej, Łęcicki Grzegorz. „Teologia mediów i komunikacji - na styku nauk o mediach oraz nauk teologicznych." Studia Medioznawcze (2016) 2: 11-24.

Benedykt XVI. Orędzie na 43. Światowy Dzień Środków Społecznego Przekazu „Nowe technologie, nowe relacje. Trzeba rozpowszechniać kulturę szacunku, dialogu i przyjaźni”, 24 stycznia 2009 r. Dostęp 4 października 2020. <https://www.paulus.org.pl/224,43-sdssp-benedykt-xvi-2009>

Domaszk, Arkadiusz. „Środki komunikacji społecznej w nauczaniu Kościoła i misji ewangelizacyjnej." Seminare (2013) 1: 81-95.

Franciszek. Orędzie na 53. Światowy Dzień Środków Społecznego Przekazu ,Wszyscy tworzymy jedno" (Ef 4, 25). Od wirtualnych wspólnot społecznościowych do wspólnot ludzkich, 24 stycznia 2019 r. Dostęp 4 października 2020. <https://www.paulus.org.pl/214,53-swiatowy-dziensrodkow-spolecznego-przekazu-franciszek-2019>

Goban-Klas, Tomasz. Media i komunikowanie masowe. Teorie i analizy prasy, radia, telewizji i Internetu. Warszawa: Wydawnictwo naukowe PWN, 1999.

Hajduk, Ryszard. Apologetyka pastoralna. Duszpasterska odpowiedź Kościoła na wyzwania czasów wspótczesnych. Kraków: Homo Dei 2009.

Hofman, Iwona. „Paradygmaty nowej dyscypliny.” Studia Medioznawcze (2019) 4: 308-317. 
Jan Paweł II. Orędzie na 24. Światowy Dzień Środków Społecznego Przekazu „Misja Kościoła w erze komputerów”, 24 stycznia 1990 r. Dostęp 4 października 2020. <https://www.paulus. org.pl/243,24-sdssp-jan-pawel-ii-1990>

Jan Paweł II. Posynodalna adhortacja apostolska Christifideles laici. Poznań: Wydawnictwo Pallottinum, 1988.

Kloch, Józef. Internet i Kościót. Warszawa: Dom Wydawniczy Elipsa, 2011.

Kloch, Józef. Kościół w Polsce wobec Web 2.0. Kielce: Wydawnictwo Jedność, 2013.

Konik, Roman. „Najnowsze nowe media i stare nowe media. Spór o definicję nowych mediów.” Dyskurs (2016) 2: 20-39.

Krzysztofek, Kazimierz. „Status mediów cyfrowych: stare i nowe paradygmaty.” Global Media Journal - Polish Edition (2006) 1: 1-15.

Kuciński, Mariusz. Internet w Kościele - Kościót w Internecie. Cyfrowa agora przestrzeniq nowej ewangelizacji. Pelplin: Bernardinum, 2019.

Levinson, Paul. Nowe nowe media. Kraków: WAM, 2010.

Łęcicki, Grzegorz. „Kościół a media.” Media w duszpasterstwie. Red. Monika Przybysz, Tomasz Wielebski. Warszawa: Wydawnictwo UKSW 2014.

Manovich, Lev. Język nowych mediów. Warszawa: WAiP, 2006

Manovich, Lev. New Media from Borges to HTML. Cambridge, Massachusetts: MIT Press, 2003.

Mazzei, Luciano. Chiesa e comunicazione. I mass media della Santa Sede. Roma: L'erma di Bretschneider, 1997.

Nieć, Mateusz. Komunikowanie społeczne i media. Warszawa: Wolters Kluwer, 2010.

Nogowski, Jacek. „Duszpasterstwo w Polsce wobec mass mediów.” Civitas et Lex (2016) 3: 7-15.

Przybyłowski, Jan. Rola nowej ewangelizacji $w$ Kościele $i w$ świecie. Warszawa: Wydawnictwo UKSW, 2014.

Slownik wiedzy o mediach. Red. Edward Chudziński. Warszawa - Bielsko-Biała: Park Edukacja, 2007.

Sobór Watykański II. Konstytucja dogmatyczna o Kościele Lumen gentium. Poznań: Wydawnictwo Pallottinum, 2005.

Sobór Watykański II. Konstytucja duszpasterska o Kościele w świecie współczesnym Gaudium et spe. Poznań: Wydawnictwo Pallottinum, 2005.

Szpunar, Magdalena. „Czym są nowe media - próba konceptualizacji.” Studia medioznawcze (2008) 4: 31-40.

Szpunar, Magdalena. Imperializm kulturowy Internetu. Kraków: IDMiKS UJ, 2017.

Szpunar, Magdalena. W stronę nowych mediów. Toruń: Wydawnictwo Adam Marszałek, 2010.

Śniadach, Grzegorz. Parafia w dobie Internetu. Warszawa: Dom Wydawniczy Elipsa, 2019.

Umiński, Grzegorz. Diecezjalne WWW w Polsce, a Nowa Ewangelizacja. Poszukiwania teologiczno-medioznawcze. Warszawa: Dom Wydawniczy Elipsa, 2017.

Wajs, Piotr. Media społecznościowe jako przestrzeń głoszenia Słowa Bożego. Teoria i praktyka. Warszawa: Dom Wydawniczy Elipsa, 2019.

Wielebski, Tomasz. „Teologia pastoralna i duszpasterstwo w służbie ewangelizacji.” Media w duszpasterstwie. Red. Monika Przybysz, Tomasz Wielebski. Warszawa: Wydawnictwo UKSW, 2014.

Marcin Wrzos OMI (ur. 1977 r.), prezbiter, misjonarz oblat Maryi Niepokalanej, doktor teologii o specjalności misjologia i teologia środków społecznego przekazu (UKSW, 2013). Ukończył studia z zakresu nauk politycznych i dziennikarstwa (2008) oraz polonistyki (2016). Autor artykułów dotyczących misji w środkach społecznego przekazu i wykorzystania środków społecznego przekazu na misjach. Bada obecność Kościoła w Internecie. Autor czterech książek: 
Polskie czasopisma misyjne po II wojnie światowej. Studium misjologiczno-prasoznawcze, Bibliografia polskich czasopism misyjnych. Lata 1945-2013, Gtówne idee teologiczne, historia i funkcje oblackiego czasopiśmiennictwa misyjnego $w$ Polsce (1926-2016) oraz redaktor Oblates missionary press in Europe. Jest pracownikiem nieetatowym Wydziałów Teologicznych UAM i USz. Redaktor naczelny „Misyjnych Dróg” i portalu internetowego www.misyjne.pl. 
